\title{
Analisis proses metakognitif siswa tipe kepribadian idealist, artisan, guardian dan rational dalam pemecahan masalah matematika
}

\author{
Neilul Isra Pratama, Kamid, M. Haris Effendi \\ Program Studi Pendidikan Matematika, Pascasarjana, Universitas Jambi, Jambi, Indonesia \\ neilulisrapratama@gmail.com
}

\begin{abstract}
ABSTRAK
Sering kita mendengar bahwa tugas pendidikan yang paling penting adalah mengajar siswa bagaimana belajar sepanjang hidup mereka dengan cara mereka sendiri dan bagaimana siswa mengarahkan pembelajaran mereka untuk menyelesaikan suatu masalah. Tujuan dari penelitian ini adalah untuk menganalisis proses metakognitif siswa dalam memecahkan masalah matematika pada tipe kepribadian idealist, artisan, guardian dan rational di SMA Negeri 5 Kota Jambi. Jenis penelitian yang digunakan dalam penelitian ini adalah penelitian kualitatif deskriptif. Pengumpulan data dilakukan berdasarkan hasil tes kepribadian, tes tertulis dan wawancara. Berdasarkan penelitian, subjek memiliki beberapa jenis penyelesaian,terutama yang berkaitan dengan proses metakognitif siswa. Mulai dari proses awareness, regulation, dan evaluation. Dalam proses awareness, keempat tipe kepribadian dapat menulis dan menjelaskan apa yang dipahami dari masalah, tetapi untuk penyertaan gambar pada lembar jawaban hanya dilakukan oleh siswa dengan tipe kepribadian idealist dan rational. Dalam proses regulation siswa dapat menjelaskan tahapan dan rumus yang akan digunakan setelah mendapatkan hasil langkah demi langkah. Tetapi ada beberapa perbedaan dalam menentukan tahap selanjutnya, seperti siswa idealist, rational dan guardian masih melakukan proses awareness untuk menentukan tahapan berikutnya. sedangkan siswa artisan sedikit kebingungan di salah satu tahapan. Namun untuk proses evaluation siswa melakukan pemeriksaan pada situasi yang berbeda untuk tiap tipe kepribadian.
\end{abstract}

Keywords : artisan, idealist, guardian, metakognitif dan rational .

\begin{abstract}
Often we hear that the most important educational task is teaching students how to learn throughout their lives in their own way and how students know what they have learned and how students direct their learning to solve problem. The purpose of this study was to analyze the student's metacognitive processes in solving mathematical problems in terms of idealist, artisan, guardian and rational personality types in Senior High School 5 Jambi City. This type of research used in this research is descriptive qualitative research. Collecting data was carried out based on the results of personality tests, written tests and interviews. Based on the research the subject has several types of solutions, especially those related to the student's metacognitive process. Start from awareness, regulation, and evaluation. In the awareness process, all four personality types can write and explain what is understood from the problem, but for the inclusion of pictures on the answer sheet is only done by students with idealist and rational personality types. In regulation process, students can explain the stages and formulas that will be used after getting the result step by step. But there are some differences in determining the next stage, such as idealist, rational and guardian students still doing the awarness process each determines the next few stages, while the artisan students are little confused at one stage. But for the evaluation process students conduct examination in different situations for each personality type.
\end{abstract}

Keywords : artisan, idealist, guardian, metacognitive and rational .

\section{PENDAHULUAN}

Sering kita mendengar bahwa tugas pendidikan yang paling penting adalah mengajar siswa bagaimana belajar sepanjang hidupnya menurut jalannya sendiri. Tetapi bagaimana siswa belajar "bagaimana belajar"? bagaimana siswa mengetahui apa yang telah kita pelajari 
dan bagaimana siswa mengarahkan belajarnya untuk masa yang akan datang. Semua itu adalah pertanyaan-pertanyaan yang diajukan oleh konsep metakognitif. Beberapa guru saat ini kekurangan ide tentang apa yang mereka ajarkan, bagaimana mereka mengajar, serta mengujinya pengetahuan metakognitif sering diabaikan padahal sangat diperlukan dalam mencapai tujuan pendidikan. (Özsoy, \& Ataman, 2013) mengungkapkan bahwa pemecahan kasus yang efektif bisa diperoleh melalui penggunaan keterampilan metakognitif. Senada dengan Özsoy dan Ataman, (Hollingworth \& McLoughlin, 2001) menyatakan bahwa pemecahan pemecahan kasus yang efektif bisa diperoleh menggunakan pemberian kesempatan pada murid untuk menerapkan proses metakognitifnya saat menuntaskan soal sebagai akibatnya bisa dikatakan bahwa metakognisi memiliki peranan krusial pada pemecahan kasus. Di sisi lain, (Kuzle, 2013) pada penelitiannya memberitahukan bahwa saat memecahkan kasus matematika, metakognisi akan membantu seorang buat mengenali eksistensi kasus yang perlu dipecahkan, tahu kasus yang sebenarnya dan tau bagaimana mencapai tujuan. Sejalan menggunakan hal tersebut, (Wilson \& Clarke, 2004) memberitajukan bahwa metakognisi bisa membantu proses berpikir seorang sebagai lebih efektif dan terbuka. Metakognisi akan membantu seorang menemukan cara-cara yang lebih efektif buat memecahkan kasus. Siswa cenderung kesulitan pada mengganti bentuk soal ke bentuk matematika yang lebih operasional. Selain itu, siswa pun kesulitan dalam aspek pengetahuan diri, subjek merasa percaya diri sanggup menuntaskan soal tersebut, namun tidak menyadari jika pengetahuannya kurang lengkap dan tidak mengetahui dengan pasti bagaimana menggunakan pengoperasiannya dengan benar sehingga dengan percaya diri bahwa langkah-langkah yang dilakukan telah benar, padahal pada penerapannya salah. Untuk mengetahui pemahaman anak didik, maka diperlukan pengetahuan tentang bagaimana sebenarnya metakognisi anak didik, bagaimana pengetahuan yang dimiliki sebelumnya dan taktik apa yang dipakai pada pemecahan masalah. Salah satu cara yang bisa dipakai buat mengetahui infonya yaitu mengungkap proses metakognitif anak didik pada pemecahan masalah seperti penelitian yang dilakukan Magiera mengenai proses metakognisi yang dibahas yaitu proses awreness, regulation, dan evaluation(Magiera \& Zawojewski, 2011).

Siswa yang mempnyai kemampuan metakognisi baik dalam pemecahan perkara akan berdampak baik pula terhadap prestasinya. Penelitian yang dilakukan (Özcan, 2014) dituliskan bahwa "students who have high metacognitive skill perform better in mathematics lesson (including problem solving) than students who have low metacognitive skill" maksudnya adalah anak didik yang mempunyai keterampilan metakognitif tinggi akan lebih baik pada pelajaran matematika (termasuk pada pemecahan kasus) daripada anak didik yang mempunyai keterampilan metakognitif rendah. Senada dengan hal tersebut, keberhasilan seorang pada memecahkan kasus sedikitnya bergantung dalam kesadarannya tentang apa yang diketahui dan bagaimana menerapkannya (Sitas, K.W., 2013). Pada penelitian yang dilakukan oleh Alfiyah dan Siswono (2014) memperlihatkan bahwa anak didik kelas VII H SMP Negeri I Puri belum bisa memakai keterampilan metakognitif yang tepat pada pemecahan suatu permasalahan. Begitu pula dalam penelitian Bulu (2015) pada penelitiannya tentang kesulitan metakognitif pada SMA Negeri I Soe menyampaikan bahwa anak didik melancholis, chorelis, sanguinis, dan phlegmatis mengalami kesulitan memakai metakognisinya pada pemecahan kasus matematika dalam materi peluang. Berdasarkan penelitian-penelitian yang menyatakan bahwa tidak seluruh anak didik sanggup memakai metakognisinya dengan baik maka hal ini menandakan masih adanya kesulitan metakognisi yang dialami anak didik pada pemecahan suatu permasalahan.

Proses berpikir seseorang ditentukan dari ciri atau karakter individu yang berkaitan dengan kepribadiannya itu sendiri (Susanto, 2006). Ciri atau karakter kepribadian individu tampak dalam dirinya baik pada tingkah laku, cara berpikir, dan cara belajar yang tidak selalu sama antara individu. Kepribadian yang tidak selaras dalam setiap individu 
ternyata bisa digolongkan menurut kecenderungan sampai mendapatkan penggolongan tipe kepribadian. Maka dari itu, peneliti memilih untuk menganalisis proses metakognisi siswa tipe kepribadian idealist, artisan, guardian dan rational dalam pemecahan masalah matematika.

\section{METODE PENELITIAN}

Metode dalam penelitian ini menggunakan tahapan penelitian kualitatif yaitu (1) identifikasi masalah penelitian, (2) Tinjauan Literatur, (3) Tujuan Khusus dan Pertanyaan Penelitian, (4) Pengumpulan Data, (5) Analisis dan Interpretasi Data, (6) Laporan dan Evaluasi Penelitian.

Dilakukannya identifikasi masalah penelitian yang mengidentifikasi suatu masalah dapat melihat situasi dimana siswa dapat menafsirkan beragam perspektif yang terlibat dalam penjelasan dan pencarian konsensus matematis. Prosedur pengumpulan data yang digunakan pada penelitian iniadalah dengan memberikan lembar tes kepribadian dilanjutkan dengan tes pemecahan masalah matematika dan wawancara kepa subjek penelitian serta mengobservasi pada setiap proses penelitian. Proses yang menjadi fokus dalam penyelesaian masalah siswa yaitu proses awreness, regulation, dan evaluation. Populasi dalam penelitian ini adalah siswa SMA yang telah mempelajari materi trigonometri dan untuk kemudahan aksesibilitas, maka dipilih siswa kelas XI IPA SMA Negeri 5 Kota Jambi. Secara keseluruhan populasi yang digunakan sebanyak 29 siswa. Dari 29 siswa ini diklasifikasikan menjadi 4 kelompok tipe kepribadian, kemudian dari masing-masing tipe kepribadian dipilih 1 orang siswa untuk dilakukan tes tertulis. Dan pada tahap akhir instrumen digunakan 4 orang siswa untuk dilakukan wawancara dari masing-masing tipe kepribadian.

Sedangkan analisis yang dilakukan menggunakan proses pengkodingan hasil wawancara terhadap hasil tes yang diberikan yaitu setelah mengidentifikasi tema selama proses pengkodingan, peneliti dapat memanfaatka lebih jauh tema untuk membuat analisis yang lebih kompleks.

\section{HASIL DAN PEMBAHASAN}

Hasil dan pembahasan ini menguraikan tentang hasil penelitian serta pembahasan berkenaan dengan pendeskripsian proses metakognisi siswa SMA Negeri 5 Kota Jambi dalam pemecahan masalah matematika berdasarkan siswa yang memiliki tipe kepribadian idealist, artisan, guardian, dan rational. Hasil penelitian ini dimulai dari hasil angket kepribadian yang dianalisis untuk memperoleh tipe kepribadian yang akan diteliti, kemudian pemberian soal pemecahan masalah matematika dimana tidak harus mementingkan skor tertinggi dari siswa karena jawaban soal yang akan dianalisis yaitu siswa yang telah terpilih berdasarkan tipe kepribadian. Dilanjutkan dengan analisis metakognisis siswa diperoleh dari jawaban soal dan hasil wawancara yang dilakukan setelah siswa menyelesaikan permasalahan matematika yang diberikan peneliti dalam bentuk soal.

Hasil Tes Kepribadian Siswa. Data yang disajikan diperoleh berdasarkan hasil pengisian angket yang diberikan peneliti kepada siswa kelas XI IPA 6 yang terdiri dari 29 orang peserta. Hasil pengisiian angket pada kelas XI IPA 6 menunjukkan bahwa terdapat 2 orang siswa dengan tipe kepribadian Artisan, 12 orang siswa dengan tipe kepribadian Guardian, 9 orang siswa dengan tipe kepribadian Idealist, 6 orang siswa dengan tipe kepribadian Rational. Subjek pada penelitian ini hanya diambil satu sujek penelitian untuk masing-masing tipe 
kepribadian, sehingga berjumlah empat subjek yang akan diteliti. Adapun Pengelompokkan berdasarkan tipe kepribadian idealist (MD), artisan (IR), guardian (SA), dan rational (AK)

Hasil Tes Tertulis dan Wawancara Siswa. Membandingkan data tes tertulis dengan tes wawancara siswa dari masing-masing tipe kerpribadian. Hal ini dilakukan agar memperoleh data untuk mengetahui proses metakognisis siswa berdasarkan tipe kepribadiannya. Peneliti melakukan triangulasi data hasil penelitian ini, yaitu mencari kesesuaian dari satu sumber pada dua tahap yaitu tahap tes tertulis dan tahap tes wawancara dengan masing-masing tipe kepribadian. Triangulasi ini untuk menguji keabsahan data tahap proses metakognisi siswa. Triangulasi yang dimaksud adalah sebagaimana yang akan dipaparkan sesuai dengan tipe kepribadiannya berikut ini pemaparan mengenai proses metakognisi siswa dalam menyelesaikan permasalahan matematika dalam bentuk soal uraian siswa didasarkan atas tiga indikator metakognisi yaitu : 1.) awareness; 2.) regulation, 3.) evaluation.

Peneliti melakukan triangulasi data hasil penelitian dengan cara mencari kesesuaian data dari tes tertulis dan tes wawancara pada keempat tipe kepribadian. Triangulasi ini digunakan menguji keabsahan data tahap proses metakognisi siswa tipe kepribadian artisan pada Tabel 1, tipe kepribadian guardian pada Tabel (2), tipe kepribadian rational pada Tabel 3, dan tipe kepribadian idealist pada Tabel 4.

Tabel 1. Tabel Triangulasi Data Siswa dengan Tipe Kepribadian Artisan

\begin{tabular}{|c|c|c|c|}
\hline \multicolumn{2}{|c|}{$\begin{array}{l}\text { Kriteria Proses metakognisi } \\
\text { dalam pemecahan masalah }\end{array}$} & \multirow{2}{*}{$\begin{array}{l}\text { Data siswa Hasil Tes } \\
\text { Tertulis } \\
\text { Siswa mampu } \\
\text { menuliskan apa yang } \\
\text { diketahui dan ditanyakan } \\
\text { pada soal untuk lebih } \\
\text { mudah memahami. }\end{array}$} & \multirow{2}{*}{$\begin{array}{l}\text { Data siswa Hasil Wawancara } \\
\text { Siswa mampu menjelaskan apa } \\
\text { yang diketahui dan ditanyakan } \\
\text { pada soal dengan benar walaupun } \\
\text { membutuhkan dengan membaca } \\
\text { soal beulang kali }\end{array}$} \\
\hline Awarness & $\begin{array}{l}\text { Siswa mampu } \\
\text { memikirkan } \\
\text { masalah yang } \\
\text { diketahui dan } \\
\text { ditanyakandari } \\
\text { soal }\end{array}$ & & \\
\hline & $\begin{array}{l}\text { Siswa mampu } \\
\text { memikirkan } \\
\text { kesesuaian } \\
\text { gambar untuk } \\
\text { membantu } \\
\text { menyelesaikan } \\
\text { soal }\end{array}$ & $\begin{array}{l}\text { Siswa mampu } \\
\text { menyesuaikan gambar } \\
\text { menggunakan rumus } \\
\text { yang akan dipilih untuk } \\
\text { menuntaskan soal, tetapi } \\
\text { tidak mendeskripsikan } \\
\text { ulang secara tertulis }\end{array}$ & $\begin{array}{l}\text { Siswa mampu menjelaskan } \\
\text { penyesuaikan gambar dengan } \\
\text { rumus yang akan dipilih untuk } \\
\text { menyelesaikan soal, siswa merasa } \\
\text { terbantu dengan adanya gambar } \\
\text { dalam memahami soal yang } \\
\text { dimaksud }\end{array}$ \\
\hline & $\begin{array}{l}\text { Siswa mampu } \\
\text { berpikir apa } \\
\text { yang perlu } \\
\text { dilakukan untuk } \\
\text { menyelesaikan } \\
\text { masalah }\end{array}$ & $\begin{array}{l}\text { Siswa mampu } \\
\text { menuliskan jawaban } \\
\text { sesui dengan maksud } \\
\text { soal dengan menyertakan } \\
\text { langkah-langkah } \\
\text { menjawab soal }\end{array}$ & $\begin{array}{l}\text { Siswa mampu menjelaskan apa } \\
\text { yang perlu dilakukan setelah } \\
\text { mengetahui apa yang ditanya dan } \\
\text { kesesuaian gambar yang menjadi } \\
\text { petunjuk pengerjaan penyelesaian } \\
\text { masalah }\end{array}$ \\
\hline
\end{tabular}




\begin{tabular}{|c|c|c|c|}
\hline \multicolumn{2}{|c|}{$\begin{array}{l}\text { Kriteria Proses metakognisi } \\
\text { dalam pemecahan masalah }\end{array}$} & \multirow{2}{*}{$\begin{array}{l}\text { Data siswa Hasil Tes } \\
\text { Tertulis } \\
\text { Siswa mampu } \\
\text { menuliskan jawaban } \\
\text { sesui dengan maksud } \\
\text { soal dengan menyertakan } \\
\text { langkah-langkah } \\
\text { menjawab soal }\end{array}$} & \multirow{2}{*}{$\begin{array}{l}\text { Data siswa Hasil Wawancara } \\
\text { Siswa mampu menjelaskan } \\
\text { apa yang akan dilakukan untuk } \\
\text { menemukan solusi dari masalah }\end{array}$} \\
\hline Regulation & $\begin{array}{l}\text { Siswa mampu } \\
\text { menyusun } \\
\text { rancangan } \\
\text { penyelesaian } \\
\text { untuk menemukan } \\
\text { solusi berdasarkan } \\
\text { masalah } \\
\end{array}$ & & \\
\hline & $\begin{array}{l}\text { Siswa mampu } \\
\text { memecahkan } \\
\text { masalah dengan } \\
\text { langkah-langkah } \\
\text { yang dipilih }\end{array}$ & $\begin{array}{l}\text { Siswa mampu } \\
\text { menuliskan jawaban } \\
\text { sesui dengan maksud } \\
\text { soal dengan menyertakan } \\
\text { langkah-langkah } \\
\text { menjawab soal }\end{array}$ & $\begin{array}{l}\text { Siswa mampu menjelaskan } \\
\text { langkah yang dipilih setelah } \\
\text { mengetahui apa yang ditanya dan } \\
\text { kesesuaian gambar yang menjadi } \\
\text { petunjuk pengerjaan penyelesaian } \\
\text { masalah }\end{array}$ \\
\hline \multirow[t]{2}{*}{ Evaluation } & $\begin{array}{l}\text { Siswa mampu } \\
\text { memeriksa } \\
\text { ketapatan rumus } \\
\text { yang digunakan }\end{array}$ & $\begin{array}{l}\text { Siswa menulis solusi } \\
\text { jawaban dengan pandai, } \\
\text { tetapi tidak melihat } \\
\text { ataupun memeriksa } \\
\text { ulang atu tidak }\end{array}$ & $\begin{array}{l}\text { Siswa menyadari untuk memeriksa } \\
\text { ketepatan rumus setelah } \\
\text { mendapatkan hasil akhir }\end{array}$ \\
\hline & $\begin{array}{l}\text { Siswa mampu } \\
\text { memeriksa } \\
\text { kesesuaian hasil } \\
\text { pemecahan } \\
\text { masalah } \\
\text { pencapaian tujuan } \\
\text { masalah }\end{array}$ & $\begin{array}{l}\text { Siswa menulis solusi } \\
\text { jawaban dengan rapi, } \\
\text { tetapi tidak terlihat siswa } \\
\text { memeriksa ulang atau } \\
\text { tidaknya }\end{array}$ & $\begin{array}{l}\text { Siswa menyadari untuk } \\
\text { memeriksa kesesuaian hasil } \\
\text { namun setelah mendapatkan hasil } \\
\text { akhir secara keseluruhan }\end{array}$ \\
\hline
\end{tabular}

Tabel 2. Tabel Triangulasi Data Siswa dengan Tipe Kepribadian Guardian

\begin{tabular}{|c|c|c|c|}
\hline \multicolumn{2}{|c|}{$\begin{array}{l}\text { Kriteria Proses metakognisi } \\
\text { dalam pemecahan masalah }\end{array}$} & \multirow{2}{*}{$\begin{array}{l}\text { Data siswa Hasil Tes } \\
\text { Tertulis } \\
\text { Siswa tidak menuliskan } \\
\text { apa yang diketahui dan } \\
\text { ditanyakan pada soal } \\
\text { dengan lengkap hanya } \\
\text { rencana apa yang akan } \\
\text { ditentukan pada soal. }\end{array}$} & \multirow{2}{*}{$\begin{array}{l}\text { Data siswa Hasil Wawancara } \\
\text { Siswa mampu menjelaskan apa } \\
\text { yang diketahui dan ditanyakan } \\
\text { pada soal dengan benar walaupun } \\
\text { membutuhkan dengan membaca } \\
\text { soal berulang kali }\end{array}$} \\
\hline Awarness & $\begin{array}{l}\text { Siswa mampu } \\
\text { memikirkan } \\
\text { masalah yang } \\
\text { diketahui dan } \\
\text { ditanyakandari } \\
\text { soal }\end{array}$ & & \\
\hline & $\begin{array}{l}\text { Siswa mampu } \\
\text { memikirkan } \\
\text { kesesuaian } \\
\text { gambar untuk } \\
\text { membantu } \\
\text { menyelesaikan } \\
\text { soal }\end{array}$ & $\begin{array}{l}\text { Siswa mampu } \\
\text { menyesuaikan gambar } \\
\text { dengan rumus yang } \\
\text { akan dipilih untuk } \\
\text { menyelesaikan } \\
\text { soal, namun tidak } \\
\text { menggambarkan ulang } \\
\text { secara tertulis. }\end{array}$ & $\begin{array}{l}\text { Siswa mampu menjelaskan } \\
\text { penyesuaikan gambar dengan } \\
\text { rumus yang akan dipilih untuk } \\
\text { menyelesaikan soal, siswa merasa } \\
\text { terbantu untuk menentukan sudut } \\
\text { yang akan diselesaikan }\end{array}$ \\
\hline & $\begin{array}{l}\text { Siswa mampu } \\
\text { berpikir apa } \\
\text { yang perlu } \\
\text { dilakukan untuk } \\
\text { menyelesaikan } \\
\text { masalah }\end{array}$ & $\begin{array}{l}\text { Siswa mampu } \\
\text { menuliskan jawaban } \\
\text { sesui dengan maksud } \\
\text { soal dengan menyertakan } \\
\text { langkah-langkah } \\
\text { menjawab soal }\end{array}$ & $\begin{array}{l}\text { Siswa mampu menjelaskan apa } \\
\text { yang perlu dilakukan setelah } \\
\text { mengetahui apa yang ditanya dan } \\
\text { kesesuaian gambar yang menjadi } \\
\text { petunjuk pengerjaan penyelesaian } \\
\text { masalah }\end{array}$ \\
\hline
\end{tabular}


Analisis proses metakognitif siswa tipe kepribadian idealist, artisan, guardian dan rational dalam ...

\begin{tabular}{|c|c|c|c|}
\hline \multicolumn{2}{|c|}{$\begin{array}{l}\text { Kriteria Proses metakognisi } \\
\text { dalam pemecahan masalah }\end{array}$} & \multirow{2}{*}{$\begin{array}{l}\text { Data siswa Hasil Tes } \\
\text { Tertulis } \\
\text { Siswa mampu } \\
\text { menuliskan jawaban } \\
\text { sesui dengan maksud } \\
\text { soal dengan menyertakan } \\
\text { langkah-langkah } \\
\text { menjawab soal }\end{array}$} & \multirow{2}{*}{$\begin{array}{l}\text { Data siswa Hasil Wawancara } \\
\text { Siswa mampu menjelaskan } \\
\text { apa yang akan dilakukan untuk } \\
\text { menemukan solusi dari masalah }\end{array}$} \\
\hline Regulation & $\begin{array}{l}\text { Siswa mampu } \\
\text { menyusun rencana } \\
\text { penyelesaian } \\
\text { untuk menemukan } \\
\text { solusi dari } \\
\text { masalah }\end{array}$ & & \\
\hline & $\begin{array}{l}\text { Siswa mampu } \\
\text { memecahkan } \\
\text { masalah dengan } \\
\text { langkah-langkah } \\
\text { yang dipilih }\end{array}$ & $\begin{array}{l}\text { Siswa mampu } \\
\text { menuliskan jawaban } \\
\text { sesui dengan maksud } \\
\text { soal dengan menyertakan } \\
\text { langkah-langkah } \\
\text { menjawab soal }\end{array}$ & $\begin{array}{l}\text { Siswa mampu menjelaskan } \\
\text { langkah yang dipilih setelah } \\
\text { mengetahui apa yang ditanya dan } \\
\text { kesesuaian gambar yang menjadi } \\
\text { petunjuk pengerjaan penyelesaian } \\
\text { masalah }\end{array}$ \\
\hline \multirow[t]{2}{*}{ Evaluation } & $\begin{array}{l}\text { Siswa mampu } \\
\text { memeriksa } \\
\text { ketapatan rumus } \\
\text { yang digunakan }\end{array}$ & $\begin{array}{l}\text { Siswa menuliskan } \\
\text { jawaban dengan rapi } \\
\text { namun tidak terlihat } \\
\text { siswa memeriksa kembali } \\
\text { atau tidak }\end{array}$ & $\begin{array}{l}\text { Siswa merasakan ada rumus } \\
\text { yang lain tapi tidak mau } \\
\text { menggunakannya }\end{array}$ \\
\hline & $\begin{array}{l}\text { Siswa mampu } \\
\text { memeriksa } \\
\text { kesesuaian hasil } \\
\text { pemecahan } \\
\text { masalah } \\
\text { pencapaian tujuan } \\
\text { masalah }\end{array}$ & $\begin{array}{l}\text { Siswa menuliskan } \\
\text { jawaban dengan rapi } \\
\text { namun tidak terlihat } \\
\text { siswa memeriksa kembali } \\
\text { atau tidak }\end{array}$ & $\begin{array}{l}\text { Siswa sudah merasa yakin dengan } \\
\text { jawaban yang dituliskannya }\end{array}$ \\
\hline \multicolumn{4}{|c|}{ Tabel 4. Tabel Triangulasi Data Siswa dengan Tipe Kepribadian Rational } \\
\hline \multicolumn{2}{|c|}{$\begin{array}{l}\text { Kriteria Proses metakognisi } \\
\text { dalam pemecahan masalah }\end{array}$} & $\begin{array}{l}\text { Data siswa Hasil Tes } \\
\text { Tertulis }\end{array}$ & Data siswa Hasil Wawancara \\
\hline \multirow[t]{3}{*}{ Awarness } & $\begin{array}{l}\text { Siswa mampu } \\
\text { memikirkan } \\
\text { masalah yang } \\
\text { diketahui dan } \\
\text { ditanyakandari } \\
\text { soal }\end{array}$ & $\begin{array}{l}\text { Siswa menuliskan apa } \\
\text { yang diketahui dan } \\
\text { ditanyakan pada soal } \\
\text { dengan lengkap. }\end{array}$ & $\begin{array}{l}\text { Siswa mampu menjelaskan apa } \\
\text { yang diketahui dan ditanyakan } \\
\text { pada soal }\end{array}$ \\
\hline & $\begin{array}{l}\text { Siswa mampu } \\
\text { memikirkan } \\
\text { kesesuaian } \\
\text { gambar untuk } \\
\text { membantu } \\
\text { menyelesaikan } \\
\text { soal }\end{array}$ & $\begin{array}{l}\text { Siswa mampu } \\
\text { menyesuaikan gambar } \\
\text { dengan rumus yang } \\
\text { akan dipilih untuk } \\
\text { menyelesaikan } \\
\text { soal, namun tidak } \\
\text { menggambarkan ulang } \\
\text { secara tertulis. }\end{array}$ & $\begin{array}{l}\text { Siswa mampu menjelaskan } \\
\text { penyesuaikan gambar dengan } \\
\text { rumus yang akan dipilih untuk } \\
\text { menyelesaikan soal }\end{array}$ \\
\hline & $\begin{array}{l}\text { Siswa mampu } \\
\text { berpikir apa } \\
\text { yang perlu } \\
\text { dilakukan untuk } \\
\text { menyelesaikan } \\
\text { masalah }\end{array}$ & $\begin{array}{l}\text { Siswa mampu } \\
\text { menuliskan jawaban } \\
\text { sesui dengan maksud } \\
\text { soal dengan menyertakan } \\
\text { langkah-langkah } \\
\text { menjawab soal }\end{array}$ & $\begin{array}{l}\text { Siswa mampu menjelaskan apa } \\
\text { yang perlu dilakukan setelah } \\
\text { mengetahui apa yang ditanya dan } \\
\text { kesesuaian gambar yang menjadi } \\
\text { petunjuk pengerjaan penyelesaian } \\
\text { masalah }\end{array}$ \\
\hline
\end{tabular}




\begin{tabular}{|c|c|c|c|}
\hline \multicolumn{2}{|c|}{$\begin{array}{l}\text { Kriteria Proses metakognisi } \\
\text { dalam pemecahan masalah }\end{array}$} & \multirow{2}{*}{$\begin{array}{l}\text { Data siswa Hasil Tes } \\
\text { Tertulis } \\
\text { Siswa menuliskan } \\
\text { penyelesaian dengan } \\
\text { permisalan angka } \\
\text { langsung }\end{array}$} & \multirow{2}{*}{$\begin{array}{l}\text { Data siswa Hasil Wawancara } \\
\text { Siswa mampu menjelaskan } \\
\text { apa yang akan dilakukan untuk } \\
\text { menemukan solusi dari masalah } \\
\text { dengan menggunakan permisalan }\end{array}$} \\
\hline Regulation & $\begin{array}{l}\text { Siswa mampu } \\
\text { menyusun } \\
\text { rencana } \\
\text { penyelesaian } \\
\text { untuk } \\
\text { menemukan } \\
\text { solusi dari } \\
\text { masalah }\end{array}$ & & \\
\hline & $\begin{array}{l}\text { Siswa mampu } \\
\text { memecahkan } \\
\text { masalah dengan } \\
\text { langkah-langkah } \\
\text { yang dipilih }\end{array}$ & $\begin{array}{l}\text { Siswa menuliskan } \\
\text { penyelesaian dengan } \\
\text { permisalan huruf saja }\end{array}$ & $\begin{array}{l}\text { Siswa mampu menjelaskan } \\
\text { langkah yang dipilih setelah } \\
\text { mengetahui apa yang ditanya dan } \\
\text { kesesuaian gambar yang menjadi } \\
\text { salah satu acuan pengerjaan } \\
\text { penyelesaian masalah }\end{array}$ \\
\hline \multirow[t]{2}{*}{ Evaluation } & $\begin{array}{l}\text { Siswa mampu } \\
\text { memeriksa } \\
\text { ketapatan rumus } \\
\text { yang digunakan }\end{array}$ & $\begin{array}{l}\text { Siswa menuliskan } \\
\text { jawaban dengan rapi } \\
\text { namun tidak terlihat } \\
\text { siswa memeriksa kembali } \\
\text { atau tidak }\end{array}$ & $\begin{array}{l}\text { Siswa menyadari untuk memeriksa } \\
\text { ketepatan rumus setelah } \\
\text { mendapatkan hasil akhir dan } \\
\text { merasa perlu menggunakan cara } \\
\text { yang berbeda }\end{array}$ \\
\hline & $\begin{array}{l}\text { Siswa mampu } \\
\text { memeriksa } \\
\text { kesesuaian hasil } \\
\text { pemecahan } \\
\text { masalah } \\
\text { pencapaian } \\
\text { tujuan masalah }\end{array}$ & $\begin{array}{l}\text { Siswa menuliskan } \\
\text { jawaban dengan rapi } \\
\text { namun tidak terlihat } \\
\text { siswa memeriksa kembali } \\
\text { atau tidak }\end{array}$ & $\begin{array}{l}\text { Siswa menyadari untuk } \\
\text { memeriksa kesesuaian hasil } \\
\text { namun setelah mendapatkan hasil } \\
\text { akhir secara keseluruhan }\end{array}$ \\
\hline
\end{tabular}

Tabel 5. Tabel Triangulasi Data Siswa dengan Tipe Kepribadian Idealist

\begin{tabular}{|c|c|c|c|}
\hline \multicolumn{2}{|c|}{$\begin{array}{l}\text { Kriteria Proses metakognisi } \\
\text { dalam pemecahan masalah }\end{array}$} & \multirow{2}{*}{$\begin{array}{l}\text { Data siswa Hasil Tes } \\
\text { Tertulis } \\
\text { Siswa menuliskan apa } \\
\text { yang diketahui dan } \\
\text { ditanyakan pada soal } \\
\text { dengan lengkap. }\end{array}$} & \multirow{2}{*}{$\begin{array}{l}\text { Data siswa Hasil Wawancara } \\
\text { Siswa mampu menjelaskan apa } \\
\text { yang diketahui dan ditanyakan } \\
\text { pada soal }\end{array}$} \\
\hline Awarness & $\begin{array}{l}\text { Siswa mampu } \\
\text { memikirkan } \\
\text { masalah yang } \\
\text { diketahui dan } \\
\text { ditanyakandari } \\
\text { soal }\end{array}$ & & \\
\hline & $\begin{array}{l}\text { Siswa mampu } \\
\text { memikirkan } \\
\text { kesesuaian } \\
\text { gambar untuk } \\
\text { membantu } \\
\text { menyelesaikan } \\
\text { soal }\end{array}$ & $\begin{array}{l}\text { Siswa mampu } \\
\text { menyesuaikan gambar } \\
\text { dengan rumus yang } \\
\text { akan dipilih untuk } \\
\text { menyelesaikan soal } \\
\text { dengan menggambarkan } \\
\text { ulang ilustrasi gambar } \\
\text { yang diberikan }\end{array}$ & $\begin{array}{l}\text { Siswa mampu menjelaskan } \\
\text { penyesuaikan gambar dengan } \\
\text { rumus yang akan dipilih } \\
\text { untuk menyelesaikan soal } \\
\text { walaupun siswa kurang mampu } \\
\text { mengembangkan kata-kata } \\
\text { dengan tepat dan hanya terpaku } \\
\text { pada apa yang ditulisnya }\end{array}$ \\
\hline & $\begin{array}{l}\text { Siswa mampu } \\
\text { berpikir apa } \\
\text { yang perlu } \\
\text { dilakukan untuk } \\
\text { menyelesaikan } \\
\text { masalah }\end{array}$ & $\begin{array}{l}\text { Siswa mampu menuliskan } \\
\text { jawaban sesui dengan } \\
\text { maksud soal dengan } \\
\text { menyertakan langkah- } \\
\text { langkah menjawab soal }\end{array}$ & $\begin{array}{l}\text { Siswa mampu menjelaskan apa } \\
\text { yang perlu dilakukan setelah } \\
\text { mengetahui apa yang ditanya } \\
\text { dan kesesuaian gambar yang } \\
\text { menjadi petunjuk pengerjaan } \\
\text { penyelesaian masalah. Walaupun } \\
\text { merasa bingung diawalnya untuk } \\
\text { menentukan rumus yang akan } \\
\text { digunakan }\end{array}$ \\
\hline
\end{tabular}


Analisis proses metakognitif siswa tipe kepribadian idealist, artisan, guardian dan rational dalam ...

\begin{tabular}{|c|c|c|c|}
\hline \multicolumn{2}{|c|}{$\begin{array}{l}\text { Kriteria Proses metakognisi } \\
\text { dalam pemecahan masalah }\end{array}$} & \multirow{2}{*}{$\begin{array}{l}\text { Data siswa Hasil Tes } \\
\text { Tertulis } \\
\text { Siswa menuliskan } \\
\text { penyelesaian dengan } \\
\text { lengkap }\end{array}$} & \multirow{2}{*}{$\begin{array}{l}\text { Data siswa Hasil Wawancara } \\
\text { Siswa mampu menjelaskan } \\
\text { apa yang akan dilakukan untuk } \\
\text { menemukan solusi dari masalah }\end{array}$} \\
\hline Regulation & $\begin{array}{l}\text { Siswa mampu } \\
\text { menyusun } \\
\text { rencana } \\
\text { penyelesaian } \\
\text { untuk } \\
\text { menemukan } \\
\text { solusi dari } \\
\text { masalah }\end{array}$ & & \\
\hline & $\begin{array}{l}\text { Siswa mampu } \\
\text { memecahkan } \\
\text { masalah dengan } \\
\text { langkah-langkah } \\
\text { yang dipilih }\end{array}$ & $\begin{array}{l}\text { Siswa menuliskan } \\
\text { penyelesaian dengan } \\
\text { lengkap }\end{array}$ & $\begin{array}{l}\text { Siswa mampu menjelaskan } \\
\text { langkah yang dipilih setelah } \\
\text { mengetahui apa yang ditanya dan } \\
\text { kesesuaian gambar yang menjadi } \\
\text { salah satu acuan pengerjaan } \\
\text { penyelesaian masalah }\end{array}$ \\
\hline \multirow[t]{2}{*}{ Evaluation } & $\begin{array}{l}\text { Siswa mampu } \\
\text { memeriksa } \\
\text { ketapatan rumus } \\
\text { yang digunakan }\end{array}$ & $\begin{array}{l}\text { Siswa menuliskan } \\
\text { jawaban dengan rapi } \\
\text { namun tidak terlihat } \\
\text { siswa memeriksa kembali } \\
\text { atau tidak }\end{array}$ & $\begin{array}{l}\text { Siswa menyadari untuk } \\
\text { memeriksa ketepatan rumus } \\
\text { setelah mendapatkan hasil akhir }\end{array}$ \\
\hline & $\begin{array}{l}\text { Siswa mampu } \\
\text { memeriksa } \\
\text { kesesuaian hasil } \\
\text { pemecahan } \\
\text { masalah } \\
\text { pencapaian tujuan } \\
\text { masalah }\end{array}$ & $\begin{array}{l}\text { Siswa menuliskan } \\
\text { jawaban dengan rapi } \\
\text { namun tidak terlihat } \\
\text { siswa memeriksa kembali } \\
\text { atau tidak }\end{array}$ & $\begin{array}{l}\text { Siswa menyadari untuk } \\
\text { memeriksa kesesuaian hasil } \\
\text { namun setelah mendapatkan hasil } \\
\text { akhir secara keseluruhan }\end{array}$ \\
\hline
\end{tabular}

Analisis Data. Untuk lebih mengetahui proses metakognisi siswa dilakukan wawancara mendalam kepada masing-masing siswa setelah proses tes tertulis selesai. Proses metakognitif dikelompokkan menjadi tiga bagian yaitu awareness, regulation, evaluation. Dalam metakognisi awareness mencakup pernyataan yang dibuat tentang pemikiran matematik seseorang mengenai apa yang diketahui, dimana terjadinya proses pemecahan masalah dan apa yang diperlukan untuk menyelesaikannya. Sedangkan metakognisi regulation mencakup pernyataan yang dibuat tentang pemikiran matemaik seseorang mengenai tahapan strategi, penetapan tujuan, memilih strategi pemecahan masalah. Lain halnya dengan metakognisi evaluation mencakup penilaian keterbatasan berpikir, keterbatasan memilih strategi, menilai hasil, serta menilai kesulitan masalah atau pemahaman(Magiera \& Zawojewski, 2011). Selain itu, siswa dikatakan mengalami proses metakognisi jenis awareness, disaat siswa sudah mempunyai pencerahan untuk memikirkan apa yang diketahuinya terkait tugas, memikirkan apa yang harus dilakukan dan apa yang telah dilakukan dalam memecahkan masalah serta menyadari posisinya dalam pemecahan masalah. Untuk proses metakognitif regulation dapat dilihat ketika siswa bisa membuat suatu perencanaan dari solusi, menentukan suatu tujuan utama, atau bahkan mampu memilih cara baru dalam penyelsaian suatu masalah. Sedangkan untuk proses metakognitif evaluation dapat terlihat ketika siswa mampu memberikan penilaian terhadap keterbatasan proses berpikirnya, ketebatasan strategi yang dipilih ataupun digunakan, serta menentukan kualitas hasil dari pemecahan suatu masalah tersebut.

Berdasarkan hasil analisis data dan triangulasi data dapat dilihat bahwa proses metakognitif siswa tipe kepribadian artisan telah mampu menuliskan apa yang diketahuinya, yang ditanyakan serta siswa tersebut mampu menyelesaikan sesuai dengan tujuan dari soal dan siswa tersebut bisa menguraikan langkah-langkah dalam menjawab soal. Dari hasil pengkodingan wawancara terlihat bahwa siswa artisan mengetahui dengan jelas apa yang 
diketahui dan ditanyakan dari soal yang diberikan. Pada bagian ini siswa menunjukkan proses metakognisi awareness dimana siswa mampu mengetehui dan memahami apa yang diketahui dan ditanyakan pada soal. Seperti halnya hasil analisis (Panjaitan, 2015) yang menyatakan bahwa karakteristik siswa tipe artisan dalam memahami suatu permasalaha, seorang siswa telah menyadari untuk memecahkan suatu masalah diperlukan pemahaman mengenai apa yang diketahui dan apa yang ditanyakan melalui membaca dan dituliskan serta menyadari hubungan antar data yang diketahui.

Selanjutnya untuk tahap regulation siswa artisan dapat menjelaskan tahapan dan rumus yang akan digunakan setelah mendapatkan hasil dari tahap demi tahap. Walaupun terdapat sedikit kebingungan di salah satu tahapan selanjutnya yang akan dilakukan tetapi dengan melihat ilustrasi gambar soal siswa bisa melanjutkan tahapan yang akan dilakukan. Dalam hal ini siswa masih melakukan tahapan awarness saat menentukan beberapa tahapan selanjutnya yang akan digunakannya. Siswa hanya mampu menerapkan satu cara dalam menyelesaikan soal sehingga siswa tidak dapat mengembangkan idenya. Menurut (Huda, Sutawidjaja, Subanji, \& Rahardjo, 2018) saat subjek gagal mempertimbangkan efektivitas strategi yang dipilih dan berpikir bahwa tidak ada cukup informasi untuk menyelesaiakn masalah dengan demikian dapat dikatakan bahwa subjek mengalami kesalahan evaluasi metakognitif dalam mempertimbangkan kesulitan masalah tersebut.

Dalam tahapan evaluation siswa hanya melakukan pemeriksaan ketika semua tahapan telah selesai dan mendapatkan hasil akhir, sehingga proses ini hanya dilakukan sekali dalam menyelesaikan soal. Sama hal nya dengan penelitian (Panjaitan, 2015) yang menyatakan bahwa dalam mengevaluasi dan memeriksa kembali siswa menyadari jika perlu untuk mengecek kebenaran dengan mencocokkan hasilnya dengan hasil yang diketahui pada suatu masalah. Namun menurut (Huda, et al., 2018) saat subjek berpikir lagi bahwa tidak ada informasi untuk menyelesaikan masalah yang dilakukan dapat dikatakan bahwa subjek mengalami kesalahan evaluasi metakognitif dalam mempertimbangkan kesulitan masalah. Sehingga siswa artisan tidak melakukan ataupun tidak menyadari untuk menemukan informasi lain dalam menyelesaikan masalahnya. Berdasarkan indikator proses metakognisi siswa dalam pemecahan masalah matematika terlihat siswa melakukan ketiga proses tersebut dimana tidak selalu berurutan dari awerness, regulation sampai pada evaluation. Walaupun seharusnya siswa tersebut melakukan tahap evaluation disetiap penyelesaian masalah agar siswa lebih mengetahui strategi dan keterkaitan penyelesaian yang dilakukan siswa.

Berdasarkan hasil analisis data dan triangulasi data dapat terlihat bahwa suatu proses metakognitif siswa tipe kepribadian guardian dalam menyelesaikan suatu permasalahan telah mampu menuliskan informasi yang diketahui siswa setelah membaca soal. Siswa membaca soal dengan berulang kali untuk ketelitian yang sesuai. Pada proses awareness, siswa ini terlihat tidak menuliskan apa yang diketahui dan ditanyakan pada soal secara detail, namun siswa menuliskan rancangan apa yang akan digunakan untuk menyelesaikannya. Selain itu, walaupun siswa tidak menuliskan secara lengkap apa yang diketahuinya, siswa guardian dapat menjelaskan apa yang dipahaminya atau apayang diketahui dan ditanya dari membaca soal. Berbeda halnya dengan penelitian yang dilakukan oleh (Panjaitan, 2015) menyadari bahwa untuk memecahkan masalah harus memahami apa yang diketahui dan apa yang ditanyakan dengan cara membaca dan juga siswa merasa perlu untuk menulis apa yang telah diperolehnya sertaa menyadari hubungan antar unsur yang diketahui.

Dari hasil penelitian dapat dilihat bahwa siswa guardian walaupun tidak menuliskan apa yang diketahui pada lembar jawaban tetapi pada hasil wawancara siswa guardian mampu menjelaskan apa yang dipahami dari soal yang telah dibacaranya baik itu hal yang diketahui 
dan ditanyakan. Siswa ini mampu menyelesaikan dan menjawab soal sesuai dengan maksud soal, ia mampu menguraikan langkah-langkah dalam menjawab soal. Pada proses regulation, siswa dapat dapat menjelaskan tahapan dan rumus yang akan digunakan setelah mendapatkan hasil dari tahap demi tahap. Untuk setiap proses tahapan ini siswa masih melakukan proses awarness setiap menentukan beberapa tahapan selanjutnya yang akan digunakannya. Menurut (Huda, et al., 2018) saat subjek gagal mempertimbangkan efektivitas strategi yang dipilih dan berpikir bahwa tidak ada cukup informasi untuk menyelesaiakn masalah dengan demikian dapat dikatakan bahwa subjek mengalami kesalahan evaluasi metakognitif dalam mempertimbangkan kesulitan masalah tersebut.

Namun untuk proses evaluation siswa guardian tidak melakukan pengecekan kembali walau merasa terdapat cara lain yang dapat diselesaikan. Siwa guardian merasa yakin dengan jawaban yang telah diselesaikannya. Dikarenakan siswa tidak memeriksa kembali lembar jawabannya, tidak dapat terlihat proses evaluation yang baik pada siswa guardian. Menurut (Huda, et al., 2018) saat subjek mengalami kesalahan evaluasi metakognitif dalam mempertimbangkan hasilnya, subjek mengalami kesalahan ecaluasi metakognitif dalam mempertimbangkan efektivitas strategi yang dipilihnya.

Berdasarkan hasil analisis data dan triangulasi data dapat dinyatakan bahwa proses metakognisi siswa yang memiliki tipe kepribadian rational dalam menyelesaikan permasalahan matematika yaitu, siswa tipe rational mampu menuliskan informasi yang ada dalam soal setelah membaca soal. Siswa membaca soal dengan teliti dan membaca soal dengan cukup satu kali untuk dapat memahaminya. Pada proses aweness, Siswa ini sudah menuliskan apa yang diketahui dan ditanyakan pada soal secara lengkap, dan juga menggambarkan ilustrasi gambar agar mudah bagi siswa agar nilai yang ditemukan dapat dituliskan pada gambar agar mudah terlihat ukurannya. Selain itu, siswa rational dapat menjelaskan apa yang dipahaminya atau apa yang diketahui dan ditanya dari membaca soal. Dalam penelitiannya (Panjaitan, 2015) menemukan siswa rational menyadari bahwa untuk memecahkan masalah ini harus memahami apa yang diketahui dan apa yang tidak ditanyakan dengan cara membaca serta merasa perlu untuk menulis yang diketahui dan yang ditanyakan, namun juga siswa tersebut meninjau kembali kebenaran hubungan antar data yang ada.

Namun menurut (Huda, et al., 2018) saat subjek berpikir lagi bahwa tidak ada informasi untuk menyelesaikan masalah yang dilakukan dapat dikatakan bahwa subjek mengalami kesalahan evaluasi metakognitif dalam mempertimbangkan kesulitan masalah. Sehingga siswa rational tidak melakukan ataupun tidak menyadari untuk menemukan informasi lain dalam menyelesaikan masalahnya

Pada proses regulation, siswa dapat dapat menjelaskan tahapan dan rumus yang akan digunakan setelah mendapatkan hasil dari tahap demi tahap. Untuk setiap proses tahapan ini siswa masih melakukan proses awarness setiap menentukan beberapa tahapan selanjutnya yang akan digunakannya. Namun untuk proses evaluation siswa rational selalu melakukan pengecekan diakhir penyelesian jawaban, sehingga siswa menuliskan kembali cara perolehan nilai yang kedua dengan mengubah permisalan yang digunakan dengan alasan angka yang dihasilkan bilangan berkoma. Alasan itu membuat siswa rational menjadi ragu dan menuliskan cara kedua pada lembar jawabannya dan tetap tidak menyalahkan salah satu penyelesaiannya karena dianggapnya telah benar.

Berdasarkan hasil analisis data dan triangulasi data dapat dinyatakan bahwa proses metakognisi siswa yang memiliki tipe kepribadian idealist dalam menyelesaikan permasalahan matematika cukup lengkap pada tiap tahapan hampir melakukan ketiga 
proses metakognisi. Siswa tipe idealist mampu menuliskan informasi yang ada dalam soal setelah membaca soal. Siswa membaca soal dengan teliti dan perlahan yang diiringi dengan penulisan langsung apa yang diketahui dan ditanyakan. Pada proses aweness, Siswa ini sudah menuliskan apa yang diketahui dan ditanyakan pada soal secara lengkap dan siswa idealist dapat menjelaskan apa yang dipahaminya atau apa yang diketahui dan ditanya dari membaca soal. Selain itu, siswa juga menggambarkan ilustrasi gambar yang diberikan soal dengan alasan agar tidak perlu membaca ulang soal saat melakukan penyelesaian. Sedikit sama dengan hasil penelitian (Panjaitan, 2015) siswa menyadari bahwa untuk memecahkan masalah ini harus memahami apa yang diketahui dan apa yang ditanyakan dengan cara membaca dan siswa merasa perlu untuk menulis yang diketahui serta siswa menyadari hubungan antar data yang diketahui. Selain itu, siswa meninjau kembali kebenaran hubungan antar data yang ada, ternyata salah, sehingga perlu membaca ulang dan menyadari kelemahannya di bidang materi yang diujikan. Namun menurut (Huda, et al., 2018) saat subjek berpikir lagi bahwa tidak ada informasi untuk menyelesaikan masalah yang dilakukan dapat dikatakan bahwa subjek mengalami kesalahan evaluasi metakognitif dalam mempertimbangkan kesulitan masalah. Sehingga siswa artisan tidak melakukan ataupun tidak menyadari untuk menemukan informasi lain dalam menyelesaikan masalahnya.

Pada proses regulation, siswa dapat dapat menjelaskan tahapan dan rumus yang akan digunakan setelah mendapatkan hasil dari tahap demi tahap. Untuk setiap proses tahapan ini siswa masih melakukan proses awarness setiap menentukan beberapa tahapan selanjutnya yang akan digunakannya. Namun untuk proses evaluation siswa idealist beberapa kali melakukan pengecekan setelah selesai tahapan penulisan rumus. Dan juga di akhir keseluruhan penyelesaian siswa idealist melakukan pengecekan kembali karena siswa idealist merasa dirinya sedikit ceroboh sehingga perlu melakukan pengecekkan ulang secara menyeluruh.

\section{SIMPULAN DAN SARAN}

Berdasarkan hasil penelitian yang telah dipaparkan dapat disimpulkan bahwa proses metakognisi siswa tipe kepribadian dalam pemecahan masalah matematika yang ditinjau dari tipe kepribadian idealist, artisan, guardian dan rational di SMA Negeri 5 Kota Jambi memiliki beberapa tipe penyelesaian khusunya yang berkaitan dengan proses metakognisi siswa tersebut. Untuk proses awareness keempat tipe kepribadian sudah mampu dalam sudah menuliskan apa yang diketahui dan ditanyakan pada soal secara lengkap, serta dapat menjelaskan apa yang dipahami dari soal namun untuk penyertaan gambar pada lembar jawaban hanya dilakukan oleh siswa dengan tipe kepribadian idealist dan rational. Selain itu pada proses regulation, siswa dapat dapat menjelaskan tahapan dan rumus yang akan digunakan setelah mendapatkan hasil dari tahap demi tahap. Namun ada beberapa perbedaan dalam menentukan tahap selanjutnya, seperti siswa idealis, rational dan guardian masih melakukan proses awarness setiap menentukan beberapa tahapan selanjutnya, sedangkan siswa artisan sedikit kebingungan di salah satu tahapan selanjutnya tetapi dengan melihat ilustrasi gambar soal siswa bisa melanjutkan tahapan yang akan dilakukan. Namun untuk proses evaluation siswa idealist beberapa kali melakukan pengecekan setelah selesai tahapan penulisan rumus dan juga di akhir keseluruhan penyelesaian. Sedangkan siswa artisan hanya melakukan pemeriksaan ketika semua tahapan telah selesai dan mendapatkan hasil akhir, sehingga proses ini hanya dilakukan sekali dalam menyelesaikan soal. Namun untuk siswa guardian tidak melakukan pengecekan kembali walau merasa terdapat cara lain yang dapat diselesaikan. Lain halnya dengan siswa rational selalu melakukan pengecekan diakhir penyelesian jawaban. 
Berdasarkan hasil penelitian yang dilakukan dan kesimpulan diatas maka saran dari peneliti adalah hasil penelitian ini dapat dugunakan oleh guru untuk mengetahui proses metakognisi siswa dalam pemecahan matematika di beberapa tipe yang berbeda. Dapat juga dilakukan sebagai evaluasi pembelajaran matematika di SMA Negeri 5 Kota Jambi dan diharapkan dapat merancang dan mengadakan perubahan dalam pembelajaran yang sesuai dengan tingkat berpikir siswa dalam meingkatkan mutu pendidikan. Berdasarkan hasil penelitian ini siswa dapat menyadari proses metakognitifnya dan meningkatkan tingkat metakognitif siswa dalam penyelesaian masalah matematika.

\section{DAFTAR RUJUKAN}

Alfiyah, N., \& Siswono, T.Y.E. (2014). Identifikasi Kesulitan Metakognisi Siswa dalam Memecahkan Masalah Matematika. MATHEdunesa, 3(2), 131-138. Retrieved from: https://jurnalmahasiswa.unesa.ac.id/index.php/mathedunesa/

Bulu, V. R. (2015). Kesulitan Metakognisi Siswa dalam Memecahkan Masalah Matematika pada Materi Peluang Ditinjau dari Tipe Kepribadian Tipologi Hippocrates-Galenus Kelas XI MIA 1 SMA Negeri I Soe di Nusa Tenggara Timur. Disertasi. Universitas Sebelas Maret, Indonesia. Retrieved from: https://digilib.uns.ac.id/dokumen/detail/47891

Hollingworth, R. W., \& McLoughlin, C. (2001). Developing science students' metacognitive problem solving skills online. Australian Journal of Educational Technology, 17(1), 5063. DOI: $10.14742 /$ ajet.1772

Huda, N., Sutawidjaja, A., Subanji, S., \& Rahardjo, S. (2018). The errors of metacognitive evaluation on metacognitive failure of students in mathematical problem solving. Journal of Physics: Conference Series, 1008(1), 1-10. DOI: 10.1088/17426596/1008/1/012073

Kuzle, A. (2013). Patterns of metacognitive behavior during mathematics problem-solving in a dynamic geometry environment. International Electronic Journal of Mathematics Education, 8(1), 20-40. Retrieved from: https://www.iejme.com/article/patternsof-metacognitive-behavior-during-mathematics-problem-solving-in-a-dynamicgeometry

Magiera, M. T., \& Zawojewski, J. S. (2011). Characterizations of social-based and selfbased contexts associated with students'awareness, evaluation,and regulation of their thinking during small-group mathematical modeling. Journal for Research in Mathematics Education, 42(5), 486-520. DOI: 10.5951/jresematheduc.42.5.0486

Özcan, Z. C.. (2014). Assessment of Metacognition in Mathematics: Which One of Two Methods is a Better Predictor of Mathematics Achievement? International Online Journal of Educational Sciences, 6(1), 49-57. DOI: 10.15345/iojes.2014.01.006

Özsoy, G., \& Ataman, A. (2017). The effect of metacognitive strategy training on mathematical problem solving achievement. International Electronic Journal of Elementary Education, 1(2), 67-82. Retrieved from: http://www.iejee.com/index.php/IEJEE

Panjaitan, B. (2015). Karakteristik Metakognisi Siswa dalam Memecahkan Masalah matematika Berdasarkan Tipe Kepribadian. Jurnal Ilmu Pendidikan, 21(1), 19-28. DOI: 10.17977/jip.v21i1.6479

Sitas, K. W. (2013). Metakognisi siswa dalam menyelesaikan soal matematika (Studi kasus pada siswa SMP berdasarkan gender). Edumatica:Jurnal Pendidikan Matematika,3(01). DOI: $10.22437 /$ edumatica.v3i01.1411

Susanto, H. (2006). Mengembangkan Kemampuan Self Regulation untuk Meningkatkan Keberhasilan Akademik Siswa. Jurnal Pendidikan Penabur, 07, 64-71. Retrieved from: http://www.academia.edu/download/34838935/Hal.64-71 Mengembangkan Self Regulation.pdf

Wilson, J., \& Clarke, D. (2004). Towards the modelling of mathematical metacognition. Mathematics Education Research Journal, 16(2), 25-48. DOI: 10.1007/BF03217394 